\title{
INFLUENCE OF ORGANIC MANURES AND GIBBERELLIC ACID ON GROWTH AND YIELD OF STRAWBERRY (Fragaria X ananassa DUCH.)
}

\author{
S.H. Ansary ${ }^{1 *}$, N. Mudi ${ }^{2}$, K. Barui ${ }^{3}$, A. Majumder ${ }^{3}$, N. Gayen ${ }^{2}$, A. K. Chowdhury ${ }^{2}$ \\ ${ }^{1}$ Nadia Krishi Vigyan Kendra, BCKV, ICAR, Gayeshpur, Nadia, West Bengal, India- 741234 \\ ${ }^{2}$ Hooghly Krishi Vigyan Kendra, BCKV, ICAR, Chinsurah, Hooghly, West Bengal, India- 712102 \\ ${ }^{3}$ Howrah Krishi Vigyan Kendra, BCKV, ICAR, Jagatballavpur, Howrah, West Bengal, India- 711408 \\ Received - December 28, 2020; Revision - July 21, 2021; Accepted - July 26, 2021 \\ Available Online - October 20, 2021
}

DOI: http://dx.doi.org/10.18006/2021.9(Spl-3-NRMCSSA_2021).S314.S320

KEYWORDS
Strawberry
Organic manure
Gibberellic acid
Foliar application
Yield

\begin{abstract}
A field experiment was conducted to study the effect of organic manures and growth regulators on the growth and yield of two varieties of strawberry namely 'Sweet Charlie' and 'Winter Dawn'. Six treatments were taken combining three organic manures viz. Vermicompost @ $3.0 \mathrm{t} / \mathrm{ha}$, Mustard oil cake@1.0 t/ha and Neem cake @ 1.0 t/ha and two concentrations of gibberellic acid $\left(\mathrm{GA}_{3}\right)$ viz. 75 ppm and $100 \mathrm{ppm}$ along with a control. Foliar application of $\mathrm{GA}_{3}$ was carried out at 40 and 60 days after planting whereas organic manures were applied as basal dose. Results of the study suggested that higher doses i.e. $100 \mathrm{ppm}$ of $\mathrm{GA}_{3}$ along with vermicompost exhibited more vegetative growth whereas $75 \mathrm{ppm}$ $\mathrm{GA}_{3}$ resulted in higher fruit set and yield in both the varieties. It was found that vermicompost @ 3.0 t/ha combined with $100 \mathrm{ppm} \mathrm{GA}_{3}$ recorded the highest plant height $(24.7 \mathrm{~cm}$ and $21.4 \mathrm{~cm})$ and numbers of leaves per plant (46.0 and 68.7) in both Sweet Charlie and Winter Dawn varieties, respectively. Whereas, highest fruit diameter $(3.3 \mathrm{~cm}$ and $3.4 \mathrm{~cm})$, fruit length $(4.6 \mathrm{~cm}$ and $4.8 \mathrm{~cm})$, fruit weight $(18.2 \mathrm{~g}$ and $17.9 \mathrm{~g}$ ), number of fruits per plant (24.6 and 32.0), yield per plant (447.8 g and 572.1 g) and yield per hectare (18.80 t and $24.03 \mathrm{t}$ ) were recorded under vermicompost @ $3.0 \mathrm{t} / \mathrm{ha}$ in combination with 75 ppm $\mathrm{GA}_{3}$ in both Sweet Charlie and Winter Dawn varieties, respectively. It was observed that Winter Dawn variety produced a $28.0 \%$ higher yield as compared to Sweet Charlie under the best treatment i.e. vermicompost @ 3.0 t/ha in combination with 75 ppm GA 3 .
\end{abstract}

* Corresponding author

E-mail: samsulhaqueansary@gmail.com (S.H. Ansary)

Peer review under responsibility of Journal of Experimental Biology and Agricultural Sciences.

Production and Hosting by Horizon Publisher India [HPI] (http://www.horizonpublisherindia.in/).

All rights reserved.
All the articles published by Journal of Experimental Biology and Agricultural Sciences are licensed under a Creative Commons Attribution-NonCommercial 4.0 International License Based on a work at www.jebas.org.

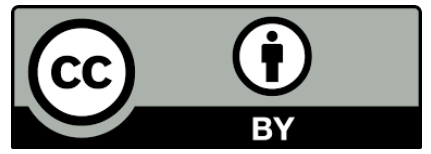




\section{Introduction}

Strawberry (Fragaria $X$ ananassa Duch) belongs to the family Rosaceae and is popular for its attractive and delicious fruits. Fruits of strawberry are consumed as fresh and also used for processing purposes. Fruits are a rich source of antioxidants, vitamin $\mathrm{C}$, and phenolic compounds. Fruits are also a rich source of minerals and nutrients and having anti-cancerous properties. In West Bengal commercial cultivation of strawberry is mainly concentrated in some pockets of North Bengal. But there is good scope for cultivation of few varieties of strawberry in South Bengal condition also as its demand remains high in metro city like Kolkata. Farmers of different parts of West Bengal started growing of strawberry and fetching good remuneration. But due to unavailability of standardized production technology and lack of technical knowhow resulting poor growth and low fruiting, farmers are facing some problems for commercial production of strawberry.

The yield of strawberry crops can be increased through improved varieties, efficient use of fertilizers, and modern agronomic practices. Improper application of nutrients is the major cause of poor growth and fruiting in strawberry crops. Application of sufficient organic matter in the soil is highly needed for successful strawberry cultivation because organic materials in the soils help to improve soil structure, enhance soil fertility, increase microbial activity, improve water holding capacity and thereby increase crop yields and vermicompost might be a suitable option for the same. Most of the plant-available nutrients like nitrates, phosphates, exchangeable calcium, and soluble potassium are present in vermicompost. Atefe et al. (2012) opined that vermicompost is eco-friendly and improves indexes of yield like fruit length, number of fruit, and fruit weight. Like vermicompost, oil cakes are also reached sources of minerals and nutrients. Mustard oil cake has unique properties that make it a favorable fertilizer. Neem cake is also an effective organic fertilizer that can also help to reduce some soil-borne pathogens. Besides, growth-regulating chemicals are also becoming relevant in strawberry cultivation for the modification of their vegetative growth, flowering, and fruiting affecting total yield and quality (Vishal et al., 2016). Foliar application of $\mathrm{GA}_{3}$ has been reported to have increased the yield and quality of different horticultural crops (Sharma \& Singh, 2009). Foliar application of gibberellic acid with optimum concentration increased the yield as compared to traditional farming (Paroussi et al., 2002). Hormones regulate plant growth and increase the yield of strawberry (Kumar et al., 2012; Khunte et al., 2014). Gibberellins promote cell division and elongation. Therefore, for better growth and production of strawberry, the application of proper nutrients and growth regulators at optimum doses and appropriate growth stages is very essential. The present study was conducted by considering the above facts and views, employing three different organic manures in combination with two different concentrations of gibberellic acid to find out the suitable organic manure along with the optimum concentration of gibberellic acid for the improvement of growth, fruit-set, and yield of strawberry.

\section{Materials and methods}

The field experiment was carried out at the Instructional farm of Hooghly Krishi Vigyan Kendra, Chinsurah, Hooghly district of West Bengal which comes under the subtropical humid region. The trial was conducted from November 2018 to March 2019. From December to January the average temperature range was reported from $15^{\circ}$ to $20^{\circ} \mathrm{C}$ while it reached $25^{\circ}$ to $30^{\circ} \mathrm{C}$ during the March to April of the study time. The soil type of the experimental field was clay loam with high water holding capacity having a $\mathrm{pH}$ of around 6.6. Two popular varieties of strawberry viz. 'Sweet Charlie' and 'Winter Dawn' were selected for the experiment. The distinguishing characteristics of the Sweet Charlie variety are earliness, cupped leaves, and tolerance to fruit rot, fruits having a unique shape, size, flavor, and sweet taste. Whereas, somewhat smaller leaves, medium to large fruits with slightly flattened in shape having sweet taste and flavor and high productive nature are some important characters of the variety, Winter Dawn. Six treatments were taken in combination with three organic manures and two concentrations of gibberellic acid $\left(\mathrm{GA}_{3}\right)$ along with a control. The details of the formulated treatments are $T_{1}$ Application of Vermicompost @ 3.0 t/ha as basal and followed by the application of $\mathrm{GA}_{3} @ 75 \mathrm{ppm}$ at $40 \mathrm{DAP}^{*}$ and $60 \mathrm{DAP}, \mathrm{T}_{2}$ Application of Vermicompost @ $3.0 \mathrm{t} / \mathrm{ha}$ as basal and followed by the application of $\mathrm{GA}_{3} @ 100 \mathrm{ppm}$ at $40 \mathrm{DAP}$ and $60 \mathrm{DAP}, \mathrm{T}_{3}$ Application of Mustard oil cake @ $1.0 \mathrm{t} / \mathrm{ha}$ as basal and followed by the application of $\mathrm{GA}_{3} @ 75 \mathrm{ppm}$ at $40 \mathrm{DAP}$ and $60 \mathrm{DAP}, \mathrm{T}_{4}$ Application of Mustard oil cake @ $1.0 \mathrm{t} / \mathrm{ha}$ as basal and followed by the application of $\mathrm{GA}_{3} @ 100 \mathrm{ppm}$ at $40 \mathrm{DAP}$ and $60 \mathrm{DAP}, \mathrm{T}_{5}$ Application of Neem cake @ $1.0 \mathrm{t} / \mathrm{ha}$ as basal and followed by the application of $\mathrm{GA}_{3} @ 75 \mathrm{ppm}$ at $40 \mathrm{DAP}$ and $60 \mathrm{DAP}, \mathrm{T}_{6}-$ Application of Neem cake @ $1.0 \mathrm{t} / \mathrm{ha}$ as basal and followed by the application of $\mathrm{GA}_{3} @ 100 \mathrm{ppm}$ at $40 \mathrm{DAP}$ and $60 \mathrm{DAP}$ and $\mathrm{T}_{7}-$ Control (application of general dose of fertilizer i.e. FYM @ 12 t/ha, NPK @ 50:80:80 kg/ha** as basal and later top dressing with water soluble NPK (19:19:19) @ 5g/L at 15 to 20 days interval and no growth regulator). Dose of NPK was taken by the following the recommendation of the division of Horticulture, ICAR Research Complex for NEH Region, Meghalaya for strawberry cultivation, and the basal dose is reduced as later water-soluble NPK was applied at a certain interval.

The design of the experiment was a randomized block design with three replications. A dose of NPK @ 50:80:80 kg/ha along with organic manure was applied as basal to all plots. Water-soluble 
NPK (19:19:19) @ 5g/L was applied as a foliar spray as top dressing fertilizer at 20 DAP, 35 DAP, 50 DAP, and 70 DAP to all plots. Micronutrient mixture ( $\mathrm{Zn}, \mathrm{B}, \mathrm{Mo}, \mathrm{Cu}) @ 2.0 \mathrm{~g} / \mathrm{L}$ was applied as a foliar spray to all plots during flowering and fruiting at $45 \mathrm{DAP}$ and 75 DAP. Black/silver plastic mulch was applied to all plots to cover the soil before planting. Saplings were planted at a spacing of $50 \mathrm{~cm}$ X $40 \mathrm{~cm}$ during $1^{\text {st }}$ week of November 2018 in an open field to accommodate around 50,000 plants per hectare. Harvesting was started during $1^{\text {st }}$ week of January 2019 and continued till the last week of March 2019. The observations like plant height, number of leaves per plant, days to first flowering, number of fruits per plant, the diameter of fruits, length of fruits, average fruit weight, and yield were recorded and analyzed statistically.

\section{Results}

\subsection{Vegetative growth characters}

Different treatments of organic manure and gibberellic acid influenced vegetative growth of strawberry like plant height and number of leaves per plant significantly over control in both the varieties (Table 1). It was found that plant height and the number of leaves per plant at 70 days after planting (DAP) was increased remarkably by different doses of gibberellic acid application and highest plant height $(24.7 \mathrm{~cm}$ and $21.4 \mathrm{~cm})$ and the number of leaves per plant (46.0 and 68.7) was observed by vermicompost combined with $100 \mathrm{ppm} \mathrm{GA} 3$ treatment $\left(\mathrm{T}_{2}\right)$ in both Sweet Charlie and Winter Dawn, respectively followed by $\mathrm{T}_{1}$ in case of Sweet Charlie and $\mathrm{T}_{4}$ in case of Winter Dawn. Whereas, under control $\left(\mathrm{T}_{7}\right)$ significantly lowest plant height $(19.4 \mathrm{~cm}$ and $17.6 \mathrm{~cm})$ and the number of leaves per plant (34.0 and 52.7) was recorded in Sweet Charlie and Winter Dawn, respectively. But the influence on days required for the opening first flower was not so prominent by the treatments in both the varieties, however, the Winter Dawn variety produced flowers slightly earlier (lowest 27.7 days in $\mathrm{T}_{4}$ ) than Sweet Charlie (lowest 31 days in $\mathrm{T}_{2}$ ) indicating this is varietal character.

\subsection{Fruit characters}

Different treatment combinations significantly affected fruit characters like fruit diameter and fruit length for both the varieties (Figure $1 \& 2$ ). The diameter and length of fruits were significantly increased by application of $\mathrm{GA}_{3}$ over control and the dose of $75 \mathrm{ppm} \mathrm{GA}_{3}$ resulted in a higher fruit size than 100 ppm $\mathrm{GA}_{3}$ in combination with all corresponding organic manure treatments. The highest fruit diameter $(3.3 \mathrm{~cm}$ and $3.4 \mathrm{~cm})$ and fruit length $(4.6 \mathrm{~cm}$ and $4.8 \mathrm{~cm})$ were observed under vermicompost in combination with $75 \mathrm{ppm} \mathrm{GA}_{3}$ treatment $\left(\mathrm{T}_{1}\right)$ in both Sweet Charlie and Winter Dawn varieties respectively, followed by $\mathrm{T}_{3}$. Whereas smaller fruits viz. lower fruit diameter $(2.8 \mathrm{~cm}$ and $3.0 \mathrm{~cm})$ and fruit length $(4.1 \mathrm{~cm}$ and $4.0 \mathrm{~cm})$ were recorded under control treatment i.e. without application of growth regulator in Sweet Charlie and Winter Dawn varieties, respectively.

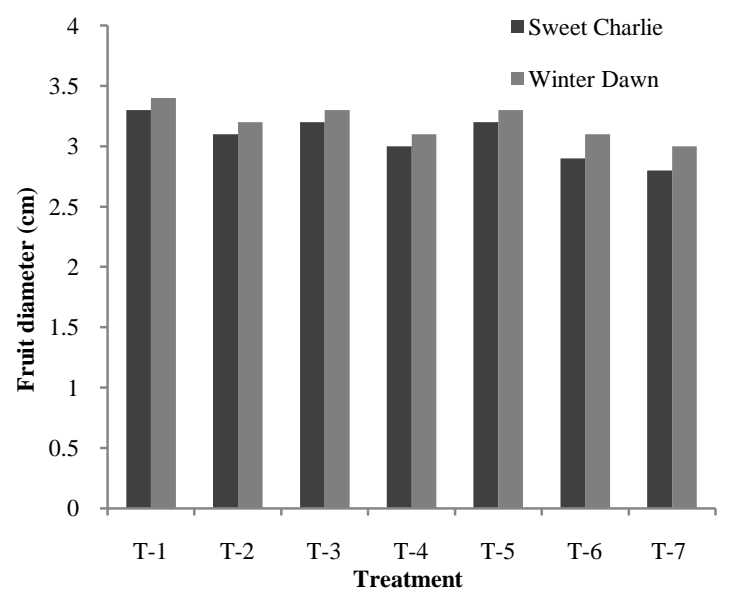

Figure 1 Effect of organic manure and gibberellic acid on fruit diameter of strawberry

Table 1 Effect of organic manure and gibberellic acid on vegetative growth of strawberry

\begin{tabular}{|cccccccc|}
\hline \multirow{2}{*}{ Treatments } & \multicolumn{2}{c}{ Plant height at 70 DAP $(\mathrm{cm})$} & \multicolumn{2}{c|}{ Number of leaves/plant at 70 DAP } & \multicolumn{2}{c|}{ Days to first flowering } \\
& Sweet Charlie & Winter Dawn & Sweet Charlie & Winter Dawn & Sweet Charlie & Winter Dawn \\
\hline $\mathrm{T}_{1}$ & 23.9 & 19.0 & 38.0 & 63.7 & 34.0 & 31.0 \\
\hline $\mathrm{T}_{2}$ & 24.7 & 21.4 & 46.0 & 68.7 & 31.0 & 27.7 \\
\hline $\mathrm{T}_{3}$ & 22.9 & 19.0 & 36.7 & 63.3 & 37.0 & 29.7 \\
\hline $\mathrm{T}_{4}$ & 23.6 & 20.9 & 37.3 & 76.3 & 34.0 & 27.7 \\
\hline $\mathrm{T}_{5}$ & 20.4 & 19.4 & 36.0 & 56.3 & 38.0 & 32.3 \\
\hline $\mathrm{T}_{6}$ & 23.3 & 20.6 & 38.7 & 71.7 & 34.7 & 28.7 \\
\hline $\mathrm{T}_{7}(\mathrm{Control})$ & 19.4 & 17.6 & 34.0 & 52.7 & 39.3 & 34.0 \\
\hline $\mathrm{SEm}( \pm)$ & 0.287 & 0.244 & 1.067 & 1.616 & 0.603 & 0.863 \\
\hline $\mathrm{CD}($ at $5 \%)$ & 0.89 & 0.75 & 3.29 & 4.98 & 1.86 & 2.66 \\
\hline
\end{tabular}

Journal of Experimental Biology and Agricultural Sciences http://www.jebas.org 


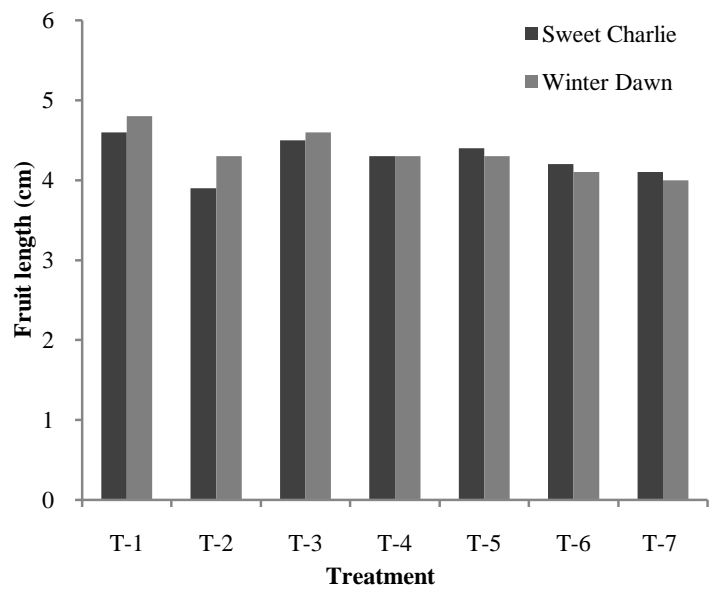

Figure 2 Effect of organic manure and gibberellic acid on fruit length of strawberry

\subsection{Yield components and yield}

Gibberellic acid treatments significantly increased the yield components and yield and the results showed that average fruit weight, the number of fruits, and yield were increased significantly by all treatment combinations over control (Figure 3, 4,5 \& 6). Vermicompost combined with $\mathrm{GA}_{3} 75 \mathrm{ppm}$ treatment $\left(\mathrm{T}_{1}\right)$ recorded the highest fruit weight $(18.2 \mathrm{~g}$ and $17.9 \mathrm{~g})$, the number of fruits per plant (24.6 and 32.0), yield per plant (447.8 g and $572.1 \mathrm{~g}$ ), and yield per hectare $(18.80 \mathrm{t}$ and $24.03 \mathrm{t})$ in both Sweet Charlie and Winter Dawn variety, respectively followed by the treatment $T_{3}$ in case of Sweet Charlie and $T_{2}$ in case of Winter Dawn variety. The lowest values in these parameters, i.e. fruit weight (15.8 g and $16.0 \mathrm{~g}$ ), number of fruits per plant (17.7 and 24.6), yield per plant (278.5 g and $394.1 \mathrm{~g}$ ), and yield per hectare (11.69 $\mathrm{t}$ and $16.55 \mathrm{t}$ ) was found under the control treatment in both Sweet Charlie and Winter Dawn variety, respectively.

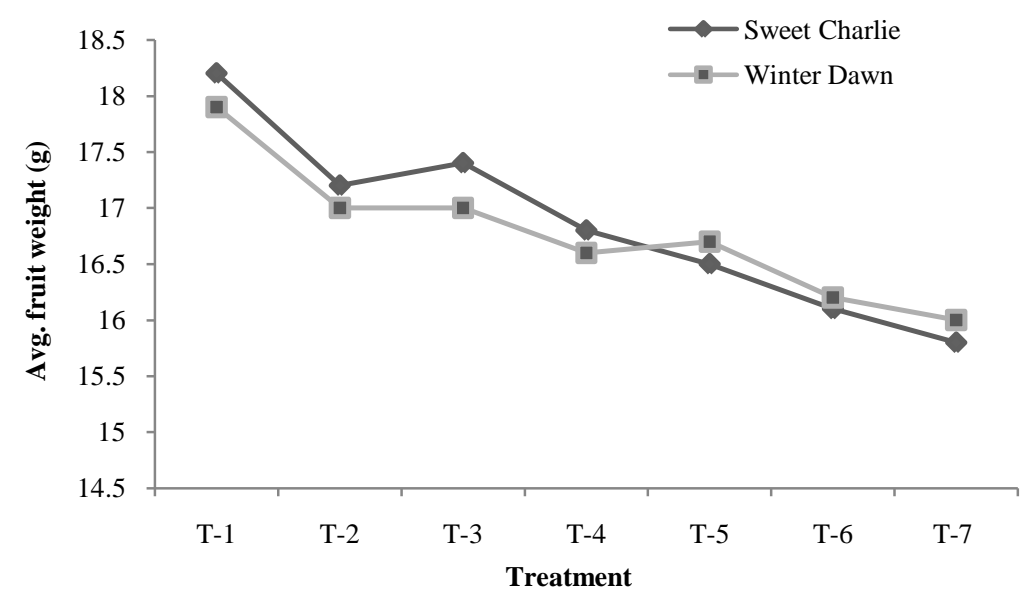

Figure 3 Effect of organic manure and gibberellic acid on avg. fruit weight of strawberry

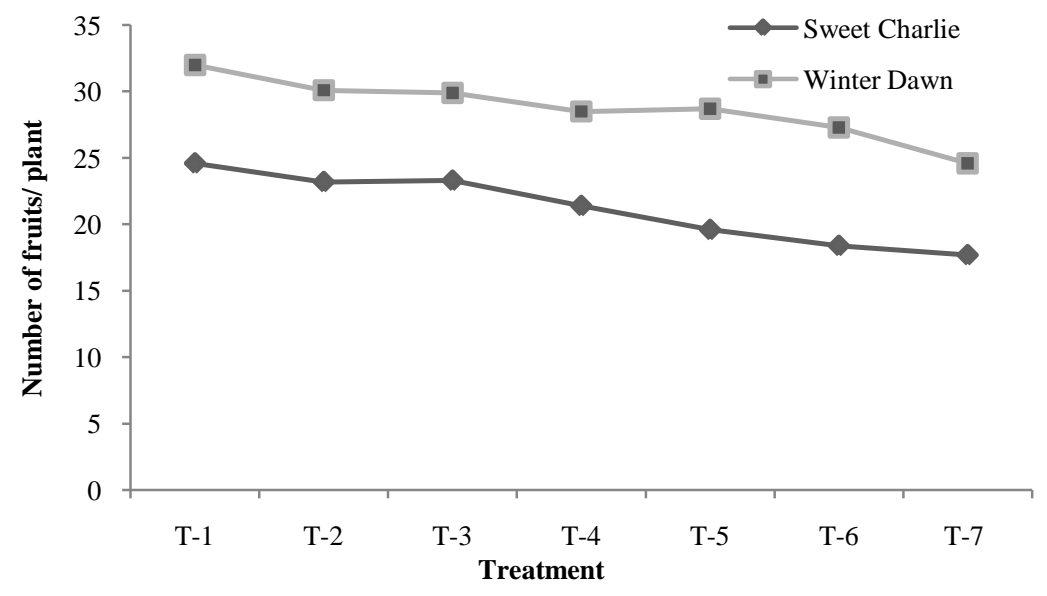

Figure 4 Effect of organic manure and gibberellic acid on number of fruits/ plant of strawberry

Journal of Experimental Biology and Agricultural Sciences http://www.jebas.org 


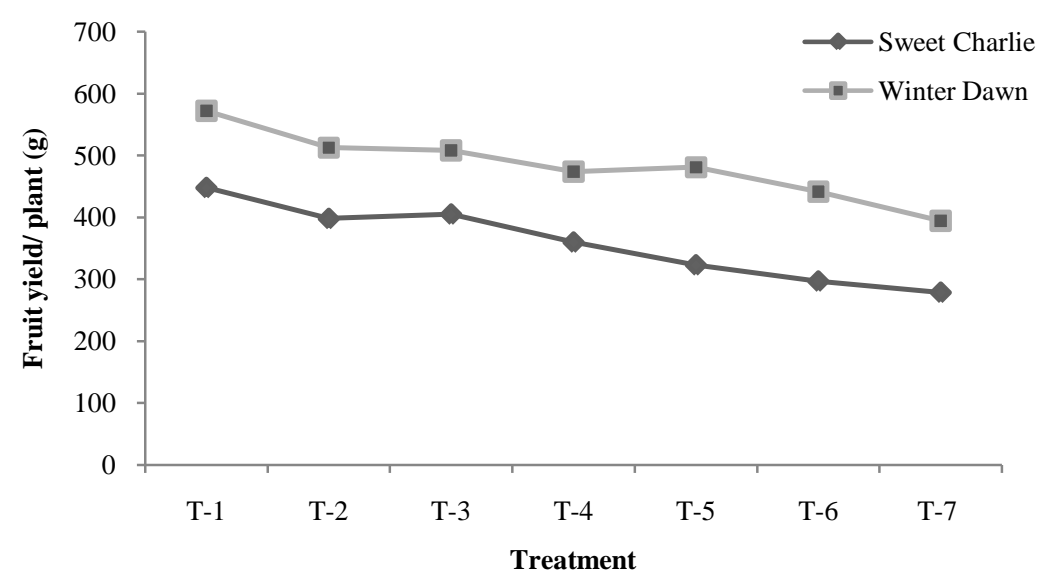

Figure 5 Effect of organic manure and gibberellic acid on fruit yield/ plant of strawberry

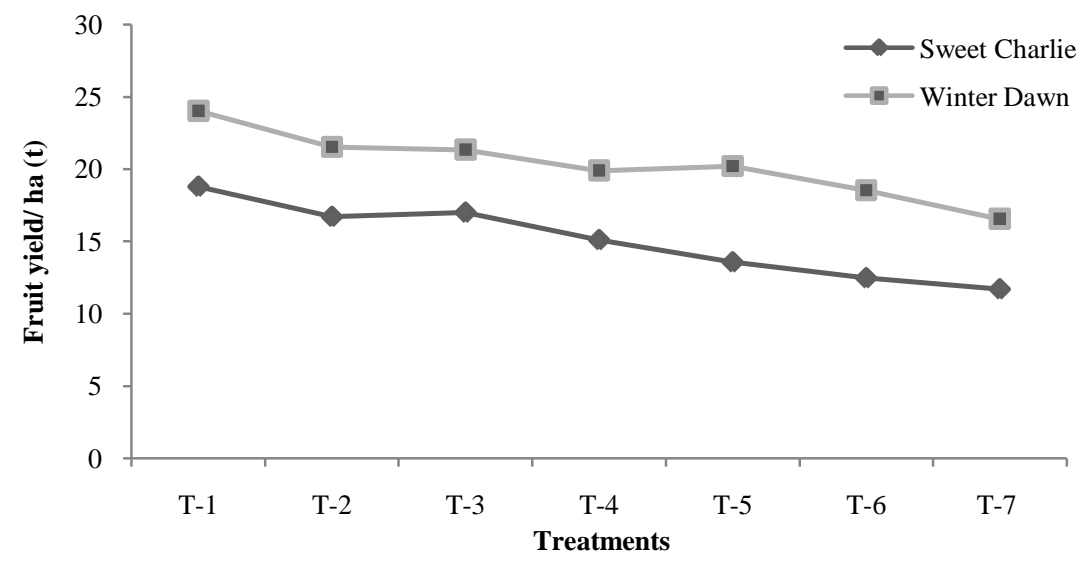

Figure 6 Effect of organic manure and gibberellic acid on fruit yield/ ha of strawberry

\section{Discussion and conclusion}

Application of $\mathrm{GA}_{3}$ exhibited higher plant height and number of leaves production which might be due to increased vegetative growth through increasing cell division and cell elongation and higher doses of $\mathrm{GA}_{3}$ influenced more. Khalid et al. (2013) reported that farmyard manure (FYM) and vermicompost-based organic amendments enhanced vegetative growth and improved the quality of strawberry fruits. Mafizur Rahman (2015) reported that among the organic fertilizers, vermicompost treated plants showed the greatest vegetative growth (plant height, number of leaves, leaf area), early flowering, and fruiting. Application of RDF + Vermicompost $5 \mathrm{t} / \mathrm{ha}+$ Neem Cake $4 \mathrm{t} / \mathrm{ha}$ was found significantly effective for strawberry in terms of plant height $(21.20 \mathrm{~cm})$ and the number of leaves per plant (16.23) as per the findings of Kumar et al. (2017). Kumar \& Tripathi (2009) revealed that strawberry plants treated with $\mathrm{GA}_{3}$ at $100 \mathrm{ppm}$ produced maximum plants height $(20.50 \mathrm{~cm})$ with the highest number of leaves $(18.75)$ which confirms the present investigation. Whereas, the best effect by 75 ppm $\mathrm{GA}_{3}$ to increase vegetative growth like plant height and leaf number of strawberry was found by Kumar et al. (2011), Sekhar et al. (2016), and Jamaluddin et al. (2012).

Increased cell division and cell elongation leading to larger fruits, i.e. increased fruit diameter and length by application of $\mathrm{GA}_{3}$ might be due to increased carbohydrate level and dry matter content because of higher photosynthesis rate. Again in combination with vermicompost 75 ppm $\mathrm{GA}_{3}$ accelerated higher fruit growth and development as compared to $100 \mathrm{ppm} \mathrm{GA}_{3}$. As reported by Mafizur Rahman (2015) the number of flowers, fruits, fruit length, fruit diameter, single fruit weight, total fruit weight/plant and yield/ha was also superior to vermicompost application. According to Saima et al. (2014) fruit, the volume and weight of strawberry were increased by growth regulators.

Higher fruit set ability by $\mathrm{GA}_{3}$ treatments might be the cause of the increasing number of fruits and higher yield might be due to the increased fruit set per plant, fruit length, and fruit diameter as well as fruit weight. Faster translocation and mobilization of stored metabolites or photosynthates from source to sink with the 
application of $\mathrm{GA}_{3}$ might be the cause of the increased number of fruits per plant. Higher fruit weight due to accelerated fruit growth and size might be due to increased cell elongation or enlargement by the exogenous application of $\mathrm{GA}_{3}$. Again, the growth of all vegetative parts were promoted by $\mathrm{GA}_{3}$ application and consequently, more food material for fruit development was produced by such plants to result in more fruit weight under the present investigation. The variety Winter Dawn produced a higher number of fruits per plant and yield as compared to Sweet Charlie though the individual fruit weight is slightly lesser in Winter Dawn. Arancon et al. (2006) reported that vermicompost application increased the growth and yields of strawberries significantly (35\% in marketable fruit weights). Application of RDF + Vermicompost $5 \mathrm{t} / \mathrm{ha}+$ Neem Cake $4 \mathrm{t} / \mathrm{ha}$ was found significantly superior for strawberry in terms of yield parameters like the number of fruits per plant (14.20), average fruit weight $(19.51 \mathrm{~g})$, fruit yield per plant $(286.56 \mathrm{~g})$ and fruit yield per hectare (17.19 t/h) as reported by Kumar et al. (2017). Sarita Paikra (2018) also reported that the foliar application of Gibberellic acid @ 100 ppm along with a recommended dose of fertilizers was found best treatment by significantly increased the plant growth, whereas plants treated with Gibberellic acid @ 75 ppm were found best in terms of yield and yield attributing parameters which conform with the present study. Saima et al. (2014) also found that the number of flowers per plant (30.22) and the number of berries (24.80) were also recorded maximum with the application of $\mathrm{GA}_{3}$ at $75 \mathrm{ppm}$ concentration. Yadav et al. (2017) reported that foliar spray of $\mathrm{GA}_{3}$ $75 \mathrm{ppm}$ after 45 days of transplanting was found superior over all other treatments for various parameters to enhance strawberry yield. The maximum number of fruits (25.9/plant), fruit weight (13.2 g), and yield $(336.6 \mathrm{~g})$ per plant were obtained with foliar application of 75 ppm $\mathrm{GA}_{3}$ as observed by Jamaluddin et al. (2012). Whereas some other researchers like Tripathi \& Shukla (2010), Singh \& Singh (2009), and Kumar \& Tripathi (2009) have reported better results in terms of yield with the higher dose, i.e. $100 \mathrm{ppm}$ of $\mathrm{GA}_{3}$.

Based on experimental results, it can be concluded that along with different organic manures applications $\mathrm{GA}_{3}$ treatments can increase the growth and yield of strawberry significantly. Along with vermicompost @ 3.0 t/ha as basal dose application of $\mathrm{GA}_{3} @$ $75 \mathrm{ppm}$ twice at $40 \mathrm{DAP}$ and $60 \mathrm{DAP}$ had the best effect to increase fruit-set, number of fruits per plant, fruit size, and yield. Other organic manures had also some positive effects to increase total fruit number per plant and yield. Under the best treatment, the Winter Dawn variety produced 28\% higher yield as compared to Sweet Charlie. Therefore, cultivation of strawberry with the application of 75 ppm GA 3 along with vermicompost @ $3.0 \mathrm{t}$ per hectare can bring ample scope for increasing crop yield in strawberry and fetch more economic return for the farmers. Again, to achieve more yields for getting better remuneration the variety Winter Dawn may be selected for commercial cultivation.

\section{Acknowledgement}

The researchers are very thankful to Project Director, Agriculture Technology Management Agency (ATMA), Hooghly for providing necessary financial assistance for conducting the research.

Conflict of Interest: The authors declare no conflict of interest.

\section{References}

Arancon NQ, Edwards CA, Bierman P (2006) Influences of vermicomposts on field strawberries. Bio-resource Technology 97(6): 831-840.

Atefe A, Tehranifar A, Shoor M, Davarynejad GH (2012) Study of the effect of vermicompost as one of the substrate constituents on yield indexes of strawberry. Journal of Horticulture Science Ornamental Plants 4(3): 241-246.

Jamaluddin AFM, Hossan MJ, Islam MS, Ahsan MK, Mehraj H (2012) Strawberry growth and yield responses to gibberellic acid concentrations. Journal of Experimental Bioscience 3(2): 51-56.

Khalid S, Qureshi KM, Hafiz IA, Khan KS, Qureshi US (2013) Effect of Organic Amendments on Vegetative Growth, Fruit and Yield Quality of Strawberry. Pakistan Journal of Agricultural Research 26(2): 104-112.

Khunte SD, Kumar A, Kumar V, Singh S, Saravanan S (2014) Effect of plant growth regulators and organic manure on physicochemical properties of strawberry (Fragaria x ananassa Duch.) cv. Chandler. International Journal of Scientific Research and Education 2(7): 158-165.

Kumar R, Bakshi P, Srivastava JN, Sravanan S (2012) Influence of plant growth regulators on growth, yield and quality of strawberry (Fragaria x ananassa Duch.) cv. Sweet Charlie. The Asian Journal of Horticulture 7(1): 40-43.

Kumar R, Mishra S, Singh S (2017) Response of organic manure with combination of micronutrient on vegetative growth and yield of strawberry (Fragaria $x$ ananassa Dutch) cv. Chandler. Journal of Pharmacognosy and Phytochemistry 6(4): 799-803.

Kumar R, Saravanan S, Bakshi P, Srivastava JN (2011) Influence of plant growth regulators on growth, yield and quality of strawberry (Fragaria $\times$ ananassa Duch.) cv. Sweet Charlie. Progressive Horticulture 43(2): 264- 267.

Kumar R, Tripathi VK (2009) Influence of NAA, $\mathrm{GA}_{3}$ and boric acid on growth, yield and quality of strawberry cv. Chandler. Progressive Horticulture 41(1): 113- 115. 
Mafizur Rahman (2015) Influence of Organic fertilizers and micronutrients on growth and yield of strawberry. M. Sc. Thesis submitted to the Department of Horticulture, Sher-E-Bangla Agriculture University, Dhaka, Pp. 92.

Paroussi G, Voyiatzis DG, Paroussi E, Drogoudi PD (2002) Growth, flowering and yield responses to GA3 of strawberry grown under different environmental conditions. Scientia Horticulturae 96(1-4): 103-113.

Saima Z, Sharma A, Umar I, Wali VK (2014) Effect of plant bioregulators on vegetative growth, yield and quality of strawberry cv. Chandler. African Journal of Agricultural Research 9(22): 16941699.

Sarita Paikra (2018) Influence of NAA and GA3 on growth, flowering, yield and quality of Strawberry (Fragaria $x$ ananassa Duch.) cv. Sabrina under net tunnel. M.Sc. (Hort.) Thesis submitted to the Department of Fruit Science, College of Agriculture, Indira Gandhi Krishi Viswavidyalaya, Raipur, Pp. 107.

Sekhar RS, Mehta K, Kumari S, Kalsi K (2016) Effect of growth regulators on growth and yield of strawberry (Fragaria $x$ ananassa Duch.) cv. Chandler. Environment and Ecology 34 (3B): 1247-1250.
Sharma RR, Singh R (2009) Gibberellic acid influences the production of malformed and button berries, and fruit yield and quality in strawberry (Fragaria $\times$ ananassa Duch.). Scientia Horticulturae 119(4): 430-433.

Singh A, Singh JN (2009) Effect of bio-regulators on growth, yield and nutrient status of strawberry cv. Sweet Charlie. Indian Journal of Horticulture 66(2): 220-224.

Tripathi VK, Shukla PK (2010) Influence of plant bio-regulators on yield and fruit characters of Strawberry cv. Chandler. Progressive Horticulture 42(2): 186-188.

Vishal VC, Thippesha D, Chethana K, Maheshgowda BM, Veeresha BG, Basavraj AK (2016) Effect of Various Growth Regulators on Vegetative parameters of strawberry (Fragaria $x$ ananassa Duch.) Cv. Sujatha. Research Journal of Chemical and Environmental Science 4(4): 68-71.

Yadav I, Singh J, Meena B, Singh P, Meena S, Neware S, Patidar DK (2017) The effect of foliar application of growth regulators and micronutrients on production of strawberry (Fragaria $x$ ananassa Duch.) cv. Winter Dawn under open field condition. Chemical Science Review and Letters 6(21): 589-594. 